\title{
Pemberdayaan Masyarakat tentang Pencegahan Penggunaan Lem Aibon pada Remaja GKI Syaloom Klademak di Kelurahan Kofkerbu Wilayah Kerja Puskesmas Remu Kota Sorong
}

\author{
${ }^{1}$ Maria Loihala, ${ }^{2}$ I Made Raka \\ 1,2Program Studi Diploma Tiga Keperawatan Sorong, Jurusan Keperawatan, Poltekkes Sorong \\ Korespondensi:Willymia050116@gmail.com
}

\begin{abstract}
Abstrak: Penyalahgunaan NAPZA salah satunya penggunaan lem telah banyak digunakan oleh remaja. Di Indonesia sekitar 14.000 orang dari 70 juta remaja berusia 12-21 tahun telah menggunakan narkoba. Penyalahgunaanlem aibon di wilayah Provinsi Papua Barat semakin mengkhawatirkan yaitu jumlah kasus mendekati angka 1.00 . Kelurahan Kofkerbu terdapat anak remaja berjumlah sekitar 32 anak sering melakukan ngelem dan belum pernahadanya kegiatan untuk menanggani remaja dalam mencegah atau menghilangkan penggunaan aibon. Hasil yang didapatkan setelah pendampingan dengan edukasi oleh Remaja PAM GKI Syaloom Klademak terjadi pemberhentian ngelem yaitu 12 ( $38 \%)$, penurunan ngelem sebanyak 14 (43\%) dan masih ngelem yaitu 6 (19 \%). Pendampingan pada anak-anak yang melakukan aktifitas ngelem sangat dibutuhkan sehingga dapat terjadi perubahan perilaku dengan menghentikan penggunaan lem aibon. Pendampingan ini butuh keterlibatan berbagai unsur baik pemerintah, tokoh agama jajaran tenaga
\end{abstract} kesehatan.

Kata Kunci :Pemberdayaan, Masyarakat, Lem Aibon, Pencegahan.

Abstract:Drug abuse, one of which is the use of glue, has been widely used by teenagers. In Indonesia,about 14,000 people out of 70 million teenagers aged 12-21 years have used drugs. The misuse of aibon glue in the West Papua Province is increasingly worrying, with the number of cases approaching 1,000. In Kofkerbu Village,there are about 32 teenagers who often do ngelem and there has never been any activity to deal with teenagers in preventing or eliminating the use of aibon. The results obtained after mentoring with education by PAM GKIYouth Syaloom Klademak there was 12 (38\%). Assistance for children who do glue activities is needed so that behavior changes can occur by stopping the use of aibon glue. This assistance requires the involvement of various elements, including the government, religious leaders and health officials.

Keywords :Empowerment, Community, Aibon Glue, Prevention.

\section{PENDAHULUAN}

Masa remaja ialah masa transisi dari anak-anak menuju dewasa. Remaja diartikan sebagai masa perkembangan transisi antara masa anak dan masa dewasa yang mencakup perubahan biologis, kognitif, dan sosial-emosional ${ }^{1}$. Pada masa-masa inilah remaja merupakan kelompok yang paling rawan berkaitan dengan penyalahgunaan NAPZA salah satunya yaitu penggunaan lem (inhalen) ${ }^{2}$. Kasus penggunaan lem semakin marak terjadi di negara-negara yang ada di dunia terutama di Indonesia, data Badan Narkotika Nasional (BNN), sekitar 1,99\%, diperkirakan pengguna mencapai 2,56\%. Remaja yang dikategorikan sebagai pengguna narkoba di Indonesia sekitar 14.000 orang dari 70 juta remaja yang berusia 12-21 tahun $^{3}$. Lem aibon merupakan unsur kimia berbahaya, lem aibon sebenarnya zat perekat yang di pakai untuk merekatkan berbagai benda seperti halnya sendal, sepatu dll, namun zat tersebut sering di salah gunakan oleh manusia. Menghirup lem aibon terhadap sesama anak dan pemuda telah menjadi momok di dataran tanah Papua. asal muasal penyebarannya belum jelas tetapi tentunya kebiasaan buruk ini datangnya dari luar tanah Papua4.Penyalahgunaan lem aibon di wilayah Provinsi Papua Barat semakin mengkhawatirkan dengan jumlah kasus yang hampir mendekati angka 1.000 di Provinsi Papua Barat. Jumlah kasus lem aibon di tahun 2017 sudah sekitar 900 kasus tertinggi tersebar di Sorong dan Manokwari. BNN Papua Barat sudah merehabilitasi sekitar 200 orang penyalahgunana aibon³.

This is an open-access article under the CC BY 4.0 International License

(C) Idea PengabdianMasyarakat (2022)

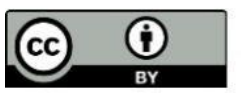

OPEN - ACCESS 
Pengguna narkoba pertama kali dan paling banyak dan rata-rata usia 16 tahun dengan jenis narkoba yang dipakai adalah ganja, ekstasi, sabu dan sekarang yang banyak dijumpai adalah ngelem ${ }^{5}$. Permasalahan Mitra yaitu kelurahan Kofkerbu anak-anak remaja yang berjumlah sekitar 48 anak sering melakukan ngelem (menghirup atau mencium bau lem aibon) namun yang bersedia menjadirepsonden sebanyak 32 anak remaja. Aktivitas ngelem ini sering dilakukan di depan taman makampahlawan. Rata-rata sehari biasa mereka ngelem 4-5 kali dengan menghabiskan 1-2 kaleng lem atau70-140 gram. Dan belum pernah adanya kegiatan untuk menanggani remaja dalam mencegah ataumenghilangkan penggunaan aibon di wilayah kerjanya. Penelitian yang dilakukan Loihala (2020) bahwaada pengaruh penyuluhan terhadap pengetahuan tentang bahaya penyalahgunaan lem aibon pada remaja di Kelurahan Kofkerbu Kota Sorong.

Solusi yang ditawarkan yaitu melakukan pemberdayaan masyarakat tentang pendampingan pencegahan penggunaan lem aibon dalam bentuk edukasi pada remaja PAM GKI Syaloom Klademak kemudian dari Remaja PAM GKI syaloom KLademak di Kelurahan Kofkerbu wilayah Kerja Puskesmas Remu Kota Sorong.

\section{METODE PELAKSANAAN}

Metode yang digunakan dalam kegiatan pengabmas ini yaitu pendampingan edukasi kepadapeserta dengan kegiatannya dilakukan melalui zoom meting sebagai berikut

\begin{tabular}{|c|c|c|c|}
\hline No & Waktu & Kegiatan Pendampingan & Kegiatan Peserta \\
\hline 1 & 20 Menit & $\begin{array}{l}\text { Pembukaan } \\
\text { a. Salam } \\
\text { b. Sambutan } \\
\text { 1. Perwakilan Peneliti } \\
\text { 2. Ketua PAM GKI } \\
\text { 3. Kepala Puskesmas } \\
\text { 4. Kabinkantibmas Polres } \\
\text { Sorong Kota }\end{array}$ & $\begin{array}{l}\text { Menjawab salam } \\
\text { dan Menyimak }\end{array}$ \\
\hline 2 & 60 Menit & $\begin{array}{l}\text { Pelaksanaan : } \\
\text { a. Materi pertama disampaikan } \\
\text { Kepala Puskesmas Remu Kota } \\
\text { b. Materi Kedua disampaikan oleh } \\
\text { Bhabinkantibmas Kota Sorong Kota } \\
\text { mengenai regulasi dan aturan } \\
\text { Penggunaan NAPZA termasuk Lem } \\
\text { Aibon }\end{array}$ & Menyimak \\
\hline 3 & 20 Menit & $\begin{array}{l}\text { Diskusi dan Tanya jawab : Beberapa } \\
\text { Pemuda bertanya ke Pihak Puskesmas } \\
\text { maupunke Babinkaptibmas Polres Sorong }\end{array}$ & $\begin{array}{l}\text { Bertanya \& } \\
\text { Menyimak }\end{array}$ \\
\hline 4 & $\begin{array}{l}10 \text { Menit } \\
\text { No }\end{array}$ & $\begin{array}{l}\text { Penutup : } \\
\text { Ucapan terima kasih untuk semua } \\
\text { yang telah berpartisipasi dan salam } \\
\text { penutup }\end{array}$ & Menjawab salam \\
\hline
\end{tabular}

Tabel 1. Planning Of Action (POA)

This is an open-access article under the CC BY 4.0 International License

(C) Idea PengabdianMasyarakat (2022)

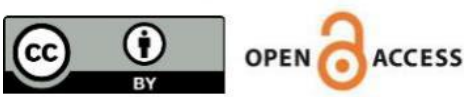




\section{HASIL DAN PEMBAHASAN}

1. Tahap Persiapan

a. Melakukan koordinasi dengan pihak Kelurahan Kofkerbu memberikan saran dan petunjuk untuk menghubungi pihak Gereja Syaloom Klademak karena anak-anak Aibon seluruhnya berada di jemaat syaloom. Kemudian pendekatan dilakukan lagi dengan pihak Puskesmas Remu Kota Sorong, dimana Jemaat GKI Syaloom Klademak merupakan wilayah kerja Puskesmas Remu. Selanjutnya tim pengabmas berkoordinasi lagi dengan pihak Polres Kota dalam hal ini Babinkabtibmas Kota Sorong.

b. Surat Menyurat

c. Persiapan Zoom Meeting

d. Persiapan sasaran

e. Menyiapkan Materi oleh Pihak Puskesmas Remu dan Babinkaptibmas Polres Sorong Kota.

\section{Tahap Pelaksanaan}

a. Pembukaaan oleh salah satu enum

b. Tim Pengabmas,Enum, sasaran dan Pemateri masuk link zoom menting

c. Sambutan oleh perwakilan tim pengabmas, Puskesmas Remu dan Babinkaptibmas Polres Sorong Kota, dan Ketua PAM GKI Syaloom Klademak

d. Tim sasaran mengisi daftar hadir

e. Memberikan penjelasan mengenai dampak lem aibon oleh Kepala Puskesmas Remu Kota Sorong

f. Sosialisasi tentang aturan atau regulasi teantang penggunaaan lem aibon oleh Bahabunkantipmas Polres Sorong Kota

g. Diskusi dan Tanya jawab

h. Penutupan dan ucapan terimakasih Tim Pengabdian masyarakat
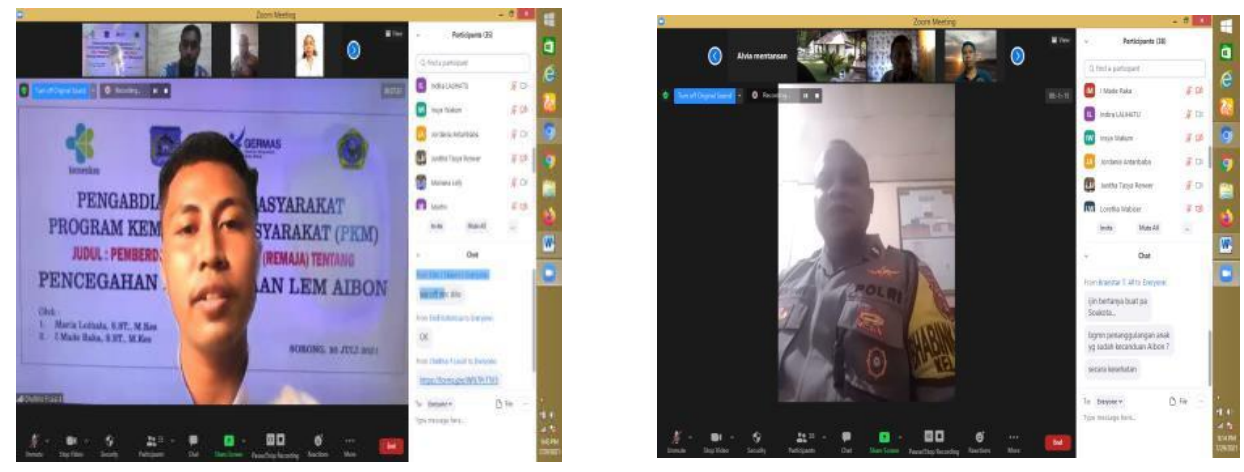

Gambar 1 dan 2. Kegiatan di Zoom Meeting

This is an open-access article under the CC BY 4.0 International 
Setelah kegiatan di lakukan pada tanggal 301 Juli 2021, selanjutnya remaja PAM GKI Syaloom melakukan pendampingan dalam bentuk edukasi tentang pencegahan penggunaan lem aibon pada anak-anak yang malukan aktfitas ngelem di Kelurahan Kofkerbu Kota Sorong. Setelah dilakukan monitoring dan evaluasi sampai dengan tanggal 31 oktober 2021 bahwa 30 remaja yang selama ini melakukan aktifitas ngelem telah mendapat pendampingan melakukan edukasi oleh Remaja PAM GKI Syaloom Klademak dimana terjadi pemberhentian ngelem yaitu 12 ( $38 \%$ ) dan penurunan penggunaan lem aibon sebanyak 14 (43\%) dan masih menggunakan lem yaitu $6(19 \%)$.

Penggunaan zat inhalen (lem aibon) adalah umum di kalangan remaja ${ }^{6}$.Banyak hal yang masih bisa dilakukan dan membantu remaja yang sudah terjerumus penyalahgunaan menghirup lem aibon, salah satunya adalah dalam bentuk pendidikan, penyebaran informasi mengenai bahaya menghirup lem aibon, pendekatan melalui keluarga, dll ${ }^{7}$.Kurangnya pengetahuan dapat diperbaiki dengan cara pemberian edukasi terstruktur atau pendidikan kesehatan dan pendampingan tentang NAPZA ${ }^{8}$. Pendidikan kesehatan dalam arti pendidikan. secara umum adalah segala upaya yang direncanakan untuk mempengaruhi orang lain, baik individu, kelompok, masyarakat, sehingga mereka melakukan apa yang diharapkan oleh pendidikan atau promosi kesehatan ${ }^{9}$.

\section{KESIMPULAN}

Pendampingan pada anak-anak yang melakukan aktifitas ngelem sangat dibutuhkan sehingga dapat terjadi perubahan perilaku dengan menghentikan penggunaan lem aibon. Pendampingan ini butuh keterlibatan berbagai unsur baik pemerintah, tokoh agama maupun jajaran kesehatan.

\section{UCAPAN TERIMAKASIH}

Terima kasih kami ucapkan untuk Kepala Puskesmas Remu Kota Sorong, Kepala Kelurhan Kofkerbu Kota Sorong, Ketua Majelis Jemaat dan Pam Remaja GKI Syaloom Klademak, BabinkaptibmasPolres Sorong Kota, enumerator, dan Poltekkes Kemenkes Sorong serta semua pihak yang telah mendukung kegiatan ini.

\section{DAFTAR PUSTAKA}

1. Ersa K, Perilaku Kecanduan Lem Aibon Pada Remaja Di Toraja Utara.[Cited2021Nov.13];Skripsi AvailableFrom:https://repository.uksw.edu/bitstream/123456789/17488/2/T1_802013141_Full\%20tex t.pdf

2. Purwanto, A. (2018). Peran Keluarga dalam Mencegah Perilaku Menyimpang Yuly Yanty Horman Benidicta Mokalu.

3. Maria Loihala (2021). Dampak Penggunaan Lem Bagi Kesehatan Remaja. Jakarta, Amertha Media.

4. Hidaya, N., \& Mardliyah, U. (2017). Dampak Penggunaan Lem Aibon pada Kalangan Anak dibawah Umur. 17-30.

5. Sari, L. (2019). Pada Anak Remaja Di Kelurahan Pelambuan Kecamatan Banjarmasin Barat Provinsi Kalimatan Selatan. Relationship between parents 'role in the behavior of inhaling glue of adolescents in kelurahan pelambuan kecamatan banjarmasin barat provinsi kalim. 2(2), 42-48.

6. Koposov, R., Stickley, A., \& Ruchkin, V. (2018). Inhalant use in adolescents in northern Russia. Social Psychiatry and Psychiatric Epidemiology, 53(7), 709-716. https://doi.org/10.1007/s00127-018-1524-z

7. Labetubun, R., Ides, S. A., \& Anggraeni, L. D. (2018). Latar Belakang Remaja Menggunakan Lem Aibon. Faletehan Health Journal, 5(1), 1-9. https://doi.org/10.33746/fhj.v5i1.2

8. Rosalina, F., Cahyani, V. P. N., \& Putri, V. R. (2019). Penyalahgunaan Lem Aibon Bagi Anak-Anak Di Kota Sorong Papua Barat. Abdimas: Papua Journal of ..., 1(1), 1-12. Retrieved from https:// core. ac.uk/ download/ pdf/235993882.pdf

9. Apriani, R., \& Sunarti, S. (2017). the Effect of Health Education Using Video on the Adolescent Knowledge About the Drug Abuse. Jnc, 4(1), 229-235

This is an open-access article under the CC BY 4.0 International License

(c) Idea PengabdianMasyarakat (2022)

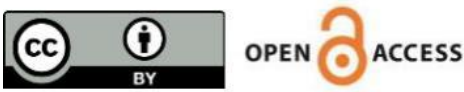


10.Rahajeng Siti Nur Rahmawati, Indah Rahmaningtyas, A. I. S. (2019). Edukasi terstruktur dan pemberdayaan anak jalanan Poltekkes Kemenkes Malang Indonesia.

11. Husna, A., Lestari, H., \& Ibrahim, K. (2016). Hubungan Pengetahuan , Teman Sebaya Dan Status Ekonomi Dengan Perilaku Ngelem Pada Anak Jalanan Di Kota Kendari Tahun 2016 the Correlation Between Knowledge , Peer Friend and Economic Status With "' Ngelem "' Behavior of Street Children in Kendari Municrip. 